\title{
Upaya Meningkatkan Pemahaman Konsep Fisika dan Kemampuan Kerja Kelompok melalui Penerapan Konstruktivisme pada Siswa Kelas VIII C SMP Negeri 1 Playen Tahun Pelajaran 2014/2015
}

\author{
Trihono \\ Guru dan Mahasiswa Program Pasca Sarjana Pendidikan Fisika UAD \\ Jalan Manthous 23 Playen Gunungkidul kode pos 5586I telepon 0274-392202 \\ Surat-e: tsmastri@gmail.com
}

\begin{abstract}
Tujuan dari penelitian ini untuk meningkatkan pemahaman konsep fisika dan kemampuan kerja kelompok siswa pada mata pelajaran fisika kelas VIIIC SMP Negeri I Playen. Metode penelitian yang digunakan adalah Penelitian Tindakan Kelas (PTK). Data penelitian berupa hasil pemahaman konsep fisika diperoleh dari test, kemampuan kerja kelompok diperoleh dari lembar observasi. Hasil analisis statistik menunjukkan pada siklus I hasil rata-rata pretes 46,72 meningkat menjadi rata-rata postes 72,97 , pada siklus II rata-rata pretes $46,4 \mathrm{I}$ meningkat menjadi rata-rata postes 74,84 , dan rata-rata pretes 47,03 meningkat menjadi rata-rata postes 77,34 pada siklus III. Sedangkan skor kemampuan kerja kelompok pada siklus I sebesar 66,56\%, pada siklus II sebesar 76,88\%, dan pada siklus III sebesar 8I,25\%. Berdasarkan hasil penelitian, pengolahan dan analisis data serta pengujian hipotesis tindakan yang telah dilakukan dalam penelitian ini, diperoleh kesimpulan bahwa pendekatan konstruktivisme dapat meningkatkan pemahaman konsep fisika dan kemampuan kerja kelompok siswa kelas VIIIC SMP Negeri I Playen.
\end{abstract}

Kata Kunci: pemahaman konsep, kemampuan kerja kelompok, pendekatan konstruktivisme.

\section{Pendahuluan}

Pembelajaran merupakan inti kegiatan dalam dunia pendidikan formal, segala sesuatu yang telah diprogramkan dilaksanakan lewat pembelajaran. Semua komponen pembelajaran yang meliputi guru dan siswa berproses di dalamnya untuk bersama-sama mencapai tujuan pembelajaran. Strategi pembelajaran apapun yang digunakan dalam proses pembelajaran hendaknya diusahakan keterlibatan fisik dan mental siswa seoptimal mungkin. Seluruh tindakan dalam proses pembelajaran seperti ini akan menciptakan kondisi belajar siswa aktif.

Pada hakikatnya belajar adalah wujud aktivitas internal pada saat terjadinya pembelajaran di kelas yang terarah dan terikat pada tujuan. Aktivitas yang dimaksud adalah aktivitas fisik dan mental siswa. Piaget [I] berpendapat bahwa, seorang anak berpikir sepanjang ia berbuat. Tanpa berbuat, anak tidak berpikir. Howard L. Kingskey dalam Syaiful Djamarah [2] menyatakan belajar merupakan proses perubahan tingkah laku yang terjadi melalui praktik dan latihan. Belajar merupakan suatu proses, suatu kegiatan bukan suatu hasil atau tujuan. Belajar bukan hanya mengingat, tetapi lebih luas yaitu mengalami.

Kenyataan di lapangan menunjukkan proses belajarmengajar di sekolah masih memerlukan banyak perbaikan. Salah satunya adalah penggunaan model pembelajaran konvensional yang kurang bervariasi atau model pembelajaran yang berpusat pada guru sehingga siswa tidak banyak melakukan aktivitas yang pada akhirnya sangat mempengaruhi semangat belajar peserta didik.

Model pembelajaran kontruktivisme menurut Vigotsky [3] merupakan pembelajaran yang mendorong siswa mengkontruksi dan menerapkan pengetahuannya, belajar memecahkan dan mendiskusikan masalah, serta berani menyampaikan ide. Paham kontruktivisme merupakan landasan dalam perkembangan model pembelajaran modern, teori ini membiasakan siswa menemukan sendiri dan mentranformasi pengetahuan yang komplek, mengecek informasi baru dengan yang lama dan merevisi jika aturan-aturan tersebut tidak sesuai lagi.

Rumusan masalah yang dicari jawabannya melalui penelitian ini adalah: Apakah melalui penerapan pendekatan konstruktivisme dapat meningkatkan penguasaan konsep fisika dan kemampuan kerja kelompok peserta didik di kelas VIIIC semester I SMP Negeri I Playen tahun pelajaran 2014/2015?

Tujuan dari penelitian ini adalah untuk mengetahui peningkatan penguasaan konsep fisika dan kemampuan kerja kelompok peserta didik di kelas VIIIC semester I SMP Negeri I Playen tahun pelajaran 2014/20I5 melalui pembelajaran konstruktiveisme. 
Upaya Meningkatkan Pemahaman Konsep Fisika dan Kemampuan Kerja Kelompok melalui Penerapan Konstruktivisme pada Siswa Kelas VIII C SMP Negeri I Playen Tahun Pelajaran 20I4/20I5

\section{Kajian Pustaka}

Menurut Bruner [4], teori konstruktivis memandang siswa membangun konsep-konsep baru atau pengetahuan yang baru diterima berdasarkan fakta dengan pengetahuan yang sudah tertanam lama di dalam otaknya dan merevisinya apabila pengetahuan tersebut tidak sesuai. Belajar adalah suatu proses aktivitas. Bruner menganggap, bahwa belajar itu meliputi tiga proses kognitif, yaitu memperoleh informasi baru, transformasi pengetahuan, dan menguji relevansi dan ketepatan pengetahuan berdasarkan pengalaman.

Menurut teori kontruktivis yang berakar dari psikologi kognitif, menjelaskan bahwa siswa merupakan hasil pembentukan makna dari pengalaman. Guru berperan sebagai fasilitator membantu siswa membentuk hubungan antara informasi baru yang dipelajari dengan informasi yang sudah diketahui siswa. Prinsip-prinsip konstruktivis yang benar-benar diterapkan di dalam kelas mengharuskan guru mengetahui apa yang telah dipahami siswa sebelum memulai pelajaran baru.

Piaget [5] menyatakan, pembentukan pengetahuan menurut teori konstruktivis memandang siswa aktif menciptakan struktur-struktur kognitif dalam interaksinya dengan lingkungan. Dengan bantuan struktur kognitif, siswa membangun pengetahuan berdasarkan pengalaman. Struktur kognitif senantiasa selalu diubah dan disesuaikan berdasarkan tuntutan lingkungan yang selalu berubah. Proses penyesuaian diri individu terjadi secara terus menerus melalui proses rekonstruksi.

Suparno[6] menyatakan, dalam teori konstruktivis yang terpenting adalah dalam proses pembelajaran siswa yang harus mendapatkan perhatian. Mereka harus aktif mengembangkan pengetahuan mereka, bukan guru maupun orang lain. Mereka harus bertanggung jawab terhadap hasil belajarnya. Penekanan siswa belajar secara aktif perlu dikembangkan.

Suparwoto [7] menyatakan bahwa produk dan sasaran pembelajaran sains adalah berupa prinsip-prinsip, konsepkonsep, dan teori ilmiah. Berdasarkan hal tersebut pembelajaran fisika dirancang dengan menekankan pada penguasaan konsep yang digeneralisasi dari pengalaman manusia dengan beberapa peristiwa dan fakta-fakta.

Conny [8] menyatakan kegitan atau keterampilan yang dapat menciptakan kondisi belajar siswa aktif atau keterampilan proses sains meliputi: observasi (pengamatan), pengukuran, perhitungan, klasifikasi, hubungan ruang dan waktu, pembuatan hipotesis, perencanaan penelitian, pengendalian variabel, interpretasi data, kesimpulan sementara, peramalan, penerapan (aplikasi), dan komunikasi.

Pengembangan keterampilan dalam pembelajaran untuk memperoleh data dan pengetahuan berperan sebagai sarana penyatu antara pengembangan konsep dan pengembangan sikap dan nilai [9]. Dengan melibatkan berbagai aktivitas untuk berinteraksi secara langsung dalam pembelajaran memberikan pengalaman yang bermakna bagi siswa. Upaya guru yang dapat dilakukan antara lain: memberi kesempatan untuk berdiskusi, melakukan percobaan, melakukan demonstrasi, dan sebagainya.

\section{Metode Penelitian}

Penelitian ini merupakan Penelitian Tindakan Kelas (PTK), sebagai upaya untuk memperbaiki dan meningkatkan mutu pembelajaran. Model penelitian dilakukan dengan mengikuti proses daur ulang atau proses siklus spiral sebanyak tiga siklus yang dikemukakan oleh Kemmis dan Mc. Taggart (Hopkins 1993, 4I). Pada model penelitian ini terdapat 4 komponen yang meliputi perenungan untuk menentukan masalah, perencanaan (planning), tindakan (acting), observasi (observing) dan refleksi (reflecting).

Subjek dalam penelitian tindakan kelas ini adalah peserta didik kelas VIIIC SMP Negeri I Playen dengan jumlah peserta didik sebanyak 32 orang yang terdiri dari I6 orang peserta didik laki-laki dan I6 orang peserta didik perempuan.

Data yang dikumpulkan pada penelitian ini meliputi observasi dan tes penguasaan konsep materi yang diajarkan dalam proses pembelajaran. Observasi dilakukan untuk mengetahui kemampuan peserta didik dalam proses pembelajaran. Dalam kegiatan observasi ini objek yang diamati adalah kegiatan siswa yang meliputi kekompakan kelompok, keaktifan kelompok, kekompakan dan ketelitian kerja. Dalam pemaparan hasil kerja antara lain: kelengkapan dan kebenaran konsep, kejelasan ucapan, keruntutan penyampaian, kelengkapam simpulan dan kemampuan menaggapi pertanyaan. Selanjutnya hasil pengamatan dimasukkan dalam lembar observasi siswa telah disiapkan. Hasil pengamatan tersebut kemudian dianalisa dengan membagi jumlah skor dibagi dengan jumlah skor total dikalikan I00\%.

Data pemahaman konsep siswa yang meliputi data pretest dan postest diambil untuk mengetahui perkembangan kemajuan pembelajaran siswa, dan data ini juga digunakan untuk mengetahui tingkat pemahaman konsep siswa. Cara menganalisis kemajuan hasil belajar siswa dengan jumlah siswa yang tuntas belajar dibagi jumlah seluruh siswa dikalikan I00\%. Ketuntasan siswa dalam belajar bila siswa dapat memperoleh nilai pretes dan posttest $\geq 70$.

\section{Hasil Penelitian dan Pembahasan}

\section{a. Hasil Penelitian}

Hasil pretest dan postest pemahaman konsep fisika siswa pada siklus I ditampilkan dalam bentuk grafik berikut: 
Upaya Meningkatkan Pemahaman Konsep Fisika dan Kemampuan Kerja Kelompok melalui Penerapan Konstruktivisme pada Siswa Kelas VIII C SMP Negeri I Playen Tahun Pelajaran 20I4/2015

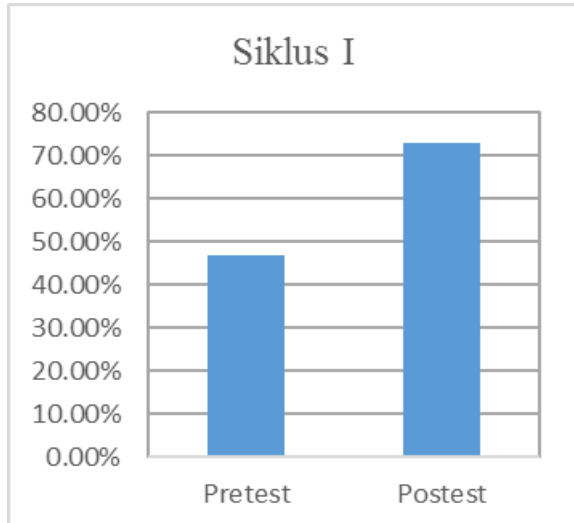

Gambar I. Grafik pretest dan postest pemahaman konsep fisika siswa pada siklus I.

Data gambar I menunjukkan bahwa nilai ketuntasan pretest sebesar $46,72 \%$ dan ketuntasan postest $72,97 \%$, dari data tersebut dapat dilihat terjadi peningkatan pemahaman konsep 26,25\%.

Hasil pretest dan postest pemahaman konsep fisika siswa pada siklus II ditampilkan dalam bentuk grafik berikut:

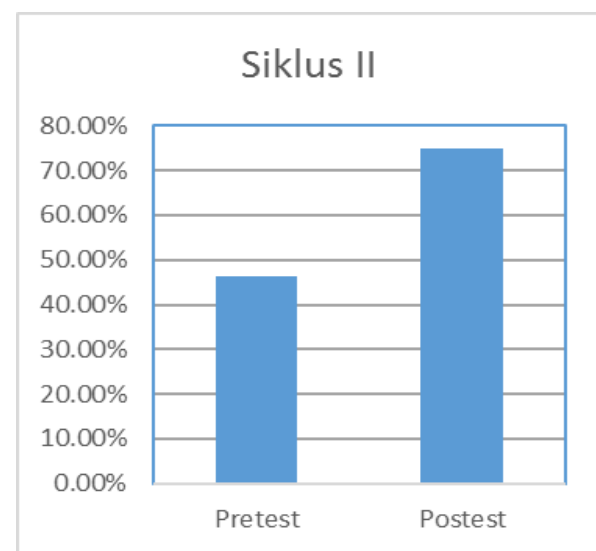

Gambar 2. Grafik pretest dan postest pemahaman konsep fisika siswa pada siklus II.

Data gambar 2 menunjukkan bahwa nilai ketuntasan pretest sebesar $46,41 \%$ dan ketuntasan postest $74,84 \%$, dari data tersebut dapat dilihat terjadi peningkatan pemahaman konsep 28,43\%.

Hasil pretest dan postest pemahaman konsep fisika siswa pada siklus III ditampilkan dalam bentuk grafik berikut:

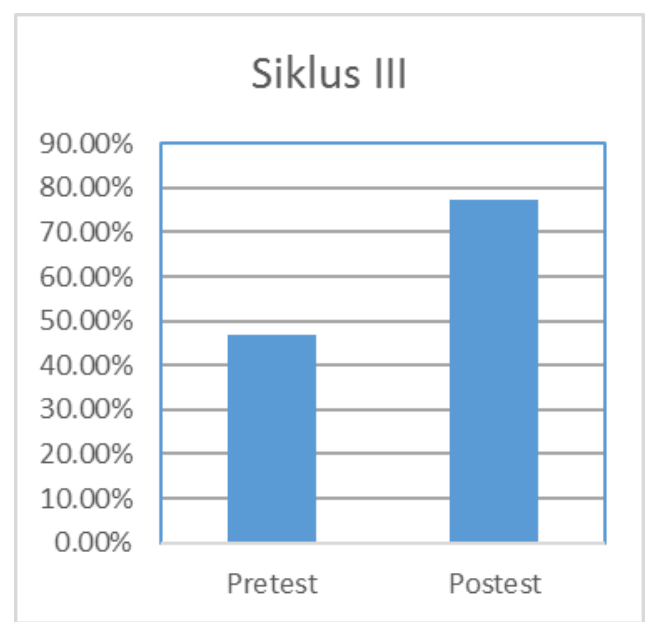

Gambar 3. Grafik pretest dan postest pemahaman konsep fisika siswa pada siklus III.

Data gambar 3 menunjukkan bahwa nilai ketuntasan pretest sebesar $47,03 \%$ dan ketuntasan postest $77,34 \%$, dari data tersebut dapat dilihat terjadi peningkatan pemahaman konsep 30,31\%.

Hasil observasi kerja kelompok pada siklus I, siklus II, dan siklus III ditampilkan dalam bentuk grafik berikut:

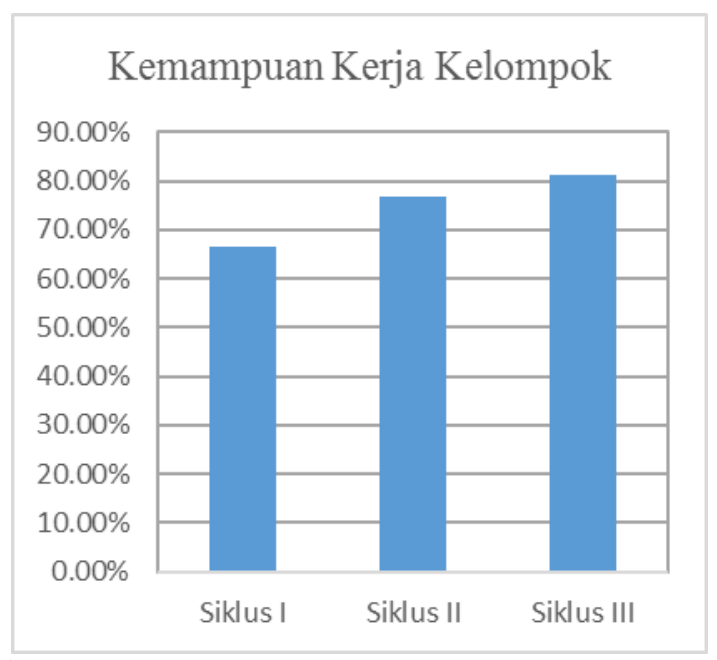

Gambar 4. Grafik hasil pengamatan kerja kelompok pada siklus I, siklus II dan siklus III.

Dari hasil observasi kemampuan kerja kelompok pada siklus I sebesar $66,56 \%$, siklus II sebesar $76,88 \%$, terjadi peningkatan sebesar I0,31\%, dan siklus III 81,25\%, sehingga terjadi kenaikan dari siklus II sebesar 4,38\%.

\section{b. Pembahasan}

Gambar grafik I menunjukkan peningkatan rata-rata pemahaman konsep fisika siklus I sebesar 26,25\% dengan nilai rata-rata pretest $46,72 \%$ dan postes $72,97 \%$.

Gambar grafik 2 menunjukkan peningkatan rata-rata pemahaman konsep fisika siklus II sebesar 28,43\% dengan nilai rata-rata pretest $46,41 \%$ dan postes $74,84 \%$. 
Gambar grafik 3 menunjukkan peningkatan rata-rata pemahaman konsep fisika siklus II sebesar 30,31\% dengan nilai rata-rata pretest $47,03 \%$ dan postes $77,34 \%$.

Hasil pemahaman konsep pada siklus I, siklus II, dan siklus III mengalami peningkatan yang baik secara berturut-turut 26,25\%, 28,43\%, dan 30,31\%. Terjadinya peningkatan rata-rata pemahaman konsep siswa ini menunjukkan bahwa penelitian tindakan kelas yang dilakukan dengan menerapkan pendekatan konstruktivisme menunjukkan hasil yang baik, sehingga dapat membantu dalam mengatasi permasalahan yang terjadi di kelas.

Dari hasil tindakan kelas yang dilakukan terjadi peningkatan kemampuan kerja kelompok dari siklus I, siklus II, dan siklus III. Hal ini terjadi karena pada siklus I siswa baru beradaptasi dengan model pembelajaran yang baru sehingga masih belum nampak keberanian untuk bertanya, berpendapat, menjawab pertanyaan bahkan presentasi. Hasil yang ditunjukkan siklus I pada nilai aktivitas belum menunjukkan hasil yang memuaskan sehingga peneliti mengevaluasi terhadap proses kegiatan tindakan kelas tersebut sebagai perbaikan pada siklus yang ke II.

Hasil tindakan pada siklus II yang diperoleh berdasarkan data observasi terjadi peningkatan kemampuan kerja kelompok siswa sebesar I0,31\% dari 66,56\% pada siklus I menjadi 76,88\% pada siklus II, dan dilanjutkan siklus III terjadi peningkatan $4,38 \%$ dari 76,88\% pada siklus II menjadi 8I,25\% pada siklus III.

Pada siklus II dan siklus III siswa sudah dapat beradaptasi dengan model pembelajaran yang baru sehingga sudah nampak keberanian untuk bertanya, berpendapat, menjawab pertanyaan bahkan presentasi. Hasil ini menunjukkan kemampuan kerja kelompok yang memuaskan sehingga penelitian tidak dilanjutkan ke siklus IV.

Dari gambar grafik di atas tampak bahwa pemahaman konsep setiap siklus untuk skor pemahaman konsep siswa dan skor kemampuan kerja kelompok peserta didik terdapat peningkatan dari siklus I ke siklus II dan ke siklus III. Artinya hipotesis tindakan diterima yaitu penerapan pendekatan konstruktivisme dapat meningkatkan pemahaman konsep dan kemampuan kerja kelompok peserta didik kelas VIIIC SMP Negeri I Playen.

\section{Kesimpulan}

Berdasarkan hasil analisa data yang diperoleh maka peneliti dapat menyimpulkan bahwa penerapan pendekatan konstruktivisme dapat meningkatkan pemahaman konsep fisika dan kemampuan kerja kelompok peserta didik kelas VIIIC SMP Negeri I Playen.
Dalam upaya peningkatan keberhasilan proses belajar mengajar hendaklah guru mencari menyebab permasalahan di kelas kemudian mencari solusi penyelesaiannya dan senantiasa melakukan penelitian untuk meningkatkan kemampuan profesional guru.

\section{Kepustakaan}

[I] Nasution, S. (2008). Berbagai Pendekatan dalam Proses Belajar dan Mengajar. Jakarta: Bumi Aksara.

[2] Syaiuful Djamarah. 2008. Psikologi Belajar. Jakarta: Rineka Cipta.

[3] Budiningsih. 2005. Belajar dan Pembelajaran. Jakarta: Rieneka Cipta.

[4] Brunner, J. (200I). Constructivist Theory. http://TIP.htm.

[5] Dahar, R.W. 1989. Teori-teori Belajar. Jakarta: Erlangga.

[6] Paul Suparno. 2007. Metodologi Pembelajaran Fisika Kontruktivis dan Menyenangkan. Yogyakarta: Universitas Sanata Dharma.

[7] Suparwoto. 1988. Pemikiran Dalam Usaha Peningkatan Proses Belajar Mengajar Fisika/IPA melalui "Concept Teaching". Yogyakarta: Jurdik Fisika FPMIPA IKIP Yogyakarta.

[8] Conny Semiawan. 1985. Keterampilan Proses. Jakarta: Gramedia.

[9] Conny Semiawan, dkk. 1988. Pendekatan Keterampilan Proses. Jakarta: Gramedia. 